FILOZOFIA

Roč. 75,2020 , č. 8

DOI: https://doi.org/10.31577/filozofia.2020.75.8.3

\title{
ARGUMENTÁCIA A PRIMÁRNE VYSVETLENIA
}

JURAJ HALAS, Filozofická fakulta Univerzity Komenského v Bratislave, Katedra logiky a metodológie vied, Bratislava, SR

HALAS, J.: Argumentation and Primary Explanations

FILOZOFIA, 75, 2020, No 8, pp. $644-659$

\begin{abstract}
Typically, a distinction is made between argumentation and explanation based on their different illocutionary aims. While the aim of argumentation is to provide support for the acceptability of a particular thesis by means of other statements, the aim of explanation is to provide understanding of a phenomenon, regularity, etc. Although this distinction is well-founded, it obscures certain interesting interactions between explanation and argumentation. This paper identifies a particular type of explanations that presuppose argumentation in their favor. These explanations refer, at least in part, to pieces of knowledge that had not been part of the preexisting knowledge base of science. Their epistemic status is therefore problematic and they require separate justification. The success of this justification (a speech act of argumentation) is one of the felicity conditions of (the speech act of) explanation. The paper proposes a general scheme of argumentation in favor of an explanation. It combines subordinative and coordinative argumentation whose aim is to show that the explanation satisfies the (often implicit) criteria of adequacy. The scheme is briefly illustrated on an example of empirical research in International Relations.
\end{abstract}

Keywords: Argumentation theory - Scientific explanation - Models of explanation - Primary and secondary understanding

\section{Úvod}

V súčasnej literatúre existuje dobre zdôvodnený konsenzus o tom, že argumentácia a vysvetl'ovanie sú rôzne druhy činnosti, ktoré sa líšia svojimi špecifickými ciel’mi. Teórie argumentácie sa preto bežne nezaoberajú analýzou, rekonštrukciou a hodnotením vysvetlení, zatial' čo filozofické teórie vedeckého vysvetlenia zvyčajne nemajú do činenia s argumentáciou. No hoci proti rozlišovaniu medzi obidvoma činnost’ami (prípadne ich výsledkami) sotva možno namietat', nazdávam sa, že pre spomínaný konsenzus sa stratili zo zretel’a ich vzájomné interakcie. Ciel’om tohto článku je ukázat', že epistemicky najzávažnejšie prípady vysvetlení bývajú podporené pomocou argumentov. Vysvetl'ovanie $\mathrm{v}$ takých prípadoch predpokladá argumentáciu, a to v tom zmysle, že úspešnost' rečového aktu argumentácie je nutnou podmienkou úspešnosti rečového aktu vysvetl'ovania. Rekonštrukcia tohto typu vysvetlení v ich úplnej po- 
dobe by preto mala zahŕňat' aj rekonštrukciu argumentov predložených na ich podporu.

V prvej časti článku sa zaoberám štandardným chápaním odlišností medzi argumentáciou a vysvetl'ovaním. Mojím ciel'om nie je spochybnit' tieto rozdiely. Chcem však - v druhej časti - poukázat' na špecifický typ vysvetl'ovania, ktoré ide ruka v ruke s argumentáciou. Štruktúru argumentácie v prospech vysvetlenia približujem v tretej časti pomocou prostriedkov pragmadialektickej teórie argumentácie. V štvrtej časti stručne ilustrujem všeobecnú schému na príklade empirického výskumu v oblasti medzinárodných vzt'ahov. Napokon záver zhŕňa najdôležitejšie zistenia.

\section{Vysvetl'ovanie verzus argumentácia}

Ak sa niekto opýta, „Prečo sa tieto kol’ajnice roztiahli?“, ktokol’vek znalý základov fyziky mu môže odpovedat' asi takto: „Roztiahli sa preto, lebo sú z kovu a slnečné lúče ich zahriali. Všetky kovy sa po zahriatí rozt'ahujú." O vysvetleniach tohto druhu, ale aj ovel’a komplikovanejších, vo filozofii vedy zvyčajne uvažujeme ako o úsudkoch. Napríklad podla klasického deduktívno-nomologického (DN) modelu má vedecké vysvetlenie podobu úsudku, ${ }^{1}$ ktorého záver (explanandum) opisuje vysvetl'ovaný jav, a ktorého premisy (explanans) zahŕňajú vhodný všeobecný zákon spolu s tvrdením, ktoré konštatuje splnenie antecedentných podmienok tohto zákona. Spomínané vysvetlenie môžeme v duchu tohto modelu rekonštruovat' takto:

(DN) Všetky kovy sa po zahriatí rozt'ahujú.

(Tieto) kol’ajnice sú z kovu a slnečné lúče ich zahriali.

(Tieto) kol'ajnice sa roztiahli.

Ide o platný deduktívny úsudok. Samozrejme to, či je aj adekvátnym DN-vysvetlením, závisí od splnenia d'alších kritérií, ktoré tento model postuluje. Vo všeobecnosti - teda aj v kontexte iných modelov explanácie - sa však vysvetl'ovanie chápe ako postup, ktorého ciel’om je sformulovat’ odpoved’ na otázku tvaru „Prečo...?“( (prípadne „Ako...?“), pričom táto odpoved” má podobu úsudku, ktorého záverom je pôvodná otázka, transformovaná do podoby oznamovacej vety.

\footnotetext{
${ }^{1}$ Ďalej používam výraz úsudok v zmysle produkt niektorej z metód usudzovania. Hoci termín argument sa často použiva ako synonymum, tu ho používam v užšom zmysle. Ako argument označujem osobitný druh úsudku, ktorý je výsledkom argumentácie, teda používania úsudkov s určitými špecifickými ciel'mi. Tie sú odlišné od ciel'ov, ktoré sledujeme pri vysvetl'ovaní, teda ked' formulujeme iný druh úsudkov (vysvetlenia). Význam tohto rozlíšenia, ako aj charakter spomínaných ciel’ov, zakrátko ozrejmím.
} 
Ak vysvetlenie má podobu úsudku, je vysvetl'ovanie - v zmysle formulovania vysvetlení - prípadom argumentácie? Sú naši dvaja komunikační aktéri, pýtajúci sa a odpovedajúci, účastníkmi procesu argumentácie? Štandardná odpoved’ je záporná. Medzi argumentmi a vysvetleniami totiž existujú významné rozdiely. Trudy Govier ich charakterizuje takto:

„[...] $\mathrm{v}$ argumente sa istota presúva od premís smerom $\mathrm{k}$ záveru, zatial' čo vo vysvetlení sa bud' vôbec nepresúva, alebo sa presúva od faktu, ktorý sa má vysvetlit', smerom k vysvetl'ujúcej hypotéze“" (Govier 2018, 248).

Tvrdenie, ktoré vystupuje v závere argumentu, je z pohl'adu recipienta neisté. Proponent záveru preto predkladá d'alšie tvrdenia, aby záver podporil. Pritom očakáva, že recipient tieto tvrdenia prijme a na základe nich prijme aj záver. V úspešnom argumente sa teda istota premís prenesie na záver. O závere vysvetlenia, naopak, neexistujú na strane pýtajúceho sa nijaké pochybnosti. Pýtajúci sa by predsa nepoložil svoju otázku, keby nebol presvedčený o tom, že kol'ajnice sa roztiahli. Vysvetlenie javu teda predpokladá, že jav už nastal (Govier 2018, 257). Tvrdenia, ktorými reaguje odpovedajúci, aby vysvetlil jav opísaný v závere, sú preto z pohl’adu recipienta rovnako, ba dokonca o čosi menej isté ako záver.

Toto rozlíšenie čelí určitým problémom. Záver vysvetlení nemusí byt' vždy $\mathrm{v}$ tomto zmysle istý. Môžeme sa pýtat', ako by veda vysvetlila jav, ktorý v skutočnosti nenastal, no mohol by nastat' - a prinajmenšom v niektorých prípadoch dostaneme legitímne, hoci hypotetické vysvetlenie. A naopak, záver argumentu nemusí byt' neistý. Napriek tomu, že tvrdenie $p$ považujeme za samozrejmé, môžeme sa zaujímat' o rôzne spôsoby, ako by sa $p$ dalo zdôvodnit', teda hl'adat' argumenty v prospech $p$.

Bez ohl'adu na tieto t’ažkosti však rozdiely pretrvávajú na pragmatickej úrovni: medzi argumentáciou a vysvetl'ovaním ako rozličnými druhmi činnosti. Ciel’om argumentácie je vždy podpora určitého tvrdenia v zmysle poskytnutia dôvodov, ktoré nás oprávňujú pokladat' dané tvrdenie za prijatel'né (van Eemeren, Grootendorst, Snoeck Henkemans 2002, xi). ${ }^{2}$ Táto charakteristika zachytáva aj prípady, ked' záver aktuálne nie je predmetom pochybností. Vysvetl'ovanie má zase za ciel' prehĺbit' niečie porozumenie (understanding). Toto porozumenie možno vymedzit' rôzne, napríklad psychologicky (vytvorenie subjektívneho pocitu pochopenia) či epistemologicky (zaradenie fenoménu do širšieho kontextu spol’ahlivých vedeckých teórií; unifikácia v zmysle zredukovania počtu navzájom nezávislých javov, ktorých existenciu musíme

\footnotetext{
${ }^{2}$ Buček a Zouhar k tomuto ciel'u argumentácie pridávajú d’alší: motiváciu určitého konania (Buček, Zouhar 2015, 142 - 143).
} 
predpokladat'; spoznanie príčin javov). ${ }^{3}$ Aj vysvetlenia hypotetických javov môžu rozšírit' naše porozumenie svetu - napríklad vtedy, ked' vo vyhrotenej forme ilustrujú potenciálne účinky skutočných kauzálnych mechanizmov.

Argumentácia a vysvetl'ovanie sú podl'a tohto vymedzenia činnosti, pri ktorých vykonávame komplexné rečové akty s „odlišným ilokučným zámerom“ (Snoeck Henkemans 2001, 232). Hoci teda DN-vysvetlenie, ktorým sme v tejto časti začali, má formu úsudku, nejde o argument v zmysle produktu argumentácie. Cielom produktora ${ }^{4}$ nie je podporit' tézu, že kol'ajnice sa roztiahli. O nej je predsa recipient už presvedčený. Produktor chce skôr pomôct' recipientovi porozumiet' procesu, ktorý viedol $\mathrm{k}$ tomu, že kol'ajnice sa roztiahli.

Pri obdivoch druhoch aktivít, argumentácii aj vysvetl'ovaní, teda používame metódy usudzovania a formulujeme úsudky, no ciele, ktoré s nimi spájame, sú odlišné. Tým sa tiež objasňuje, prečo rovnaký úsudok môže v jednom kontexte fungovat' ako argument, zatial' čo v inom pôjde o vysvetlenie:

(A/V) Zadlženie krajín EÚ rastie.

Stabilita európskej ekonomiky je vážne narušená.

Možno si predstavit' situáciu, $\mathrm{v}$ ktorej produktor presviedča recipienta o pravdivosti záveru, pričom poukazuje na najnovšie údaje Eurostatu o štátnom dlhu. V inej situácii by produktor, naopak, mohol vybrat' zadlženie štátov ako najdôležitejší spomedzi kauzálnych faktorov, ktoré vysvetl'ujú známy fakt. ${ }^{5}$ Úsudok vystupuje bud' ako argument, alebo ako vysvetlenie, no nikdy nie ako oboje naraz. Ak chceme jeho jednotlivý výskyt správne klasifikovat', musíme sa pozriet' na „kontext dialógu“ (Bex, Walton 2016, 67) a na základe jazykovej evidencie určit’ zámery účastníkov komunikácie.

\section{Primárne a sekundárne vysvetlenia}

V súčasnej literatúre teda existuje konsenzus o tom, že argumenty sa líšia od vysvetlení a že argumentácia a vysvetl'ovanie sú odlišnými druhmi činnosti. ${ }^{6}$ Analýza skutočných či ideálnych vedeckých vysvetlení vo filozofii vedy preto zvyčajne odhliada od dialogického kontextu a zaobíde sa bez prostriedkov teórie argumentácie. Na druhej strane proponenti teórií argumentácie pri vymedzovaní svojej oblasti skúmania zvyčajne

\footnotetext{
${ }^{3}$ Prehl'ad diskusií o filozofických teóriách porozumenia pozri v (De Regt 2017, 48 - 86).

${ }^{4}$ Tento všeobecný termín používam namiesto bežnejšieho výrazu hovorca, ked’že v prípade vysvetlení má komunikácia často písomnú formu.

${ }^{5}$ Pravda, $\mathrm{v}$ tomto prípade nejde o úplné vysvetlenie, ktoré by zodpovedalo niektorému z modelov vedeckého vysvetlenia. Úsudok však možno pokladat' za náčrt vysvetlenia (explanation sketch).

${ }^{6}$ Pozri tiež (Zouhar 2019, 757).
} 
zdôrazňujú, že vysvetlenia do nej nepatria. ${ }^{7}$ Mojím ciel'om nie je spochybnit' spomínané rozlíšenie ani del'bu práce, ktorá sa na ňom zakladá. Chcem však ukázat', že kognitívne najzaujímavejšie prípady vysvetl'ovania idú ruka v ruke s argumentáciou, takže epistemicky najcennejšie vysvetlenia bývajú podporené argumentmi. ${ }^{8}$

Užitočným východiskom pri identifikácii takých vysvetlení je rozlíšenie medzi primárnym a sekundárnym porozumením, ktoré zaviedol Paul Humphreys (2000). Ten si všíma, že príklady vedeckých vysvetlení, s ktorými pracuje filozofia vedy, zväčša odkazujú na všeobecne známe poznatky. Patrí medzi ne aj vysvetlenie faktu, že sa zmenil objem kolajníc, ktorým sme začali. Dialogická situácia, ktorá je v pozadí takýchto príkladov, je charakteristická tým, že pýtajúci sa trpí „epistemickým deficitom“ (Humphreys 2000, 269), ktorý možno jednoducho odstránit'. Stačí zalistovat' v učebniciach fyziky či inej empirickej vedy, prípadne položit príslušnú otázku kvalifikovanému odpovedajúcemu. Odstránenie epistemického deficitu prehlbuje porozumenie pýtajúceho sa, no ide o tzv. sekundárne porozumenie:

„Sekundárnym porozumením možno nazvat' porozumenie (resp. jeho nárast), ku ktorému dochádza, ked' jednotlivcovi alebo skupine poskytne iný jednotlivec či skupina všetky prvky poznania, ktoré potrebuje, aby dospel k určitej (zlepšenej) úrovni porozumenia“" (Humphreys 2000, 269).

Podl’a Humphreysa sú však najdôležitejšie tie otázky tvaru „Prečo...?“, ktoré sa kladú v čase, ked’ nie je známa odpoved'. Ich zodpovedanie prináša primárne porozumenie, ktoré dosahujeme vtedy,

„ked’ jednotlivec alebo skupina objaví aspoň jednu dosial' neznámu entitu, ktorá umožňuje postúpit' $\mathrm{k}$ (vylepšenému) vysvetleniu určitého javu, alebo ked’ jednotlivec či skupina bez pomoci iných nanovo objaví kroky, ktoré urobil skorší objavitel"“ (Humphreys 2000, 269).

Primárne porozumenie vzniká - aspoň sčasti - v kontexte objavu, zatial’ čo sekundárne porozumenie sa opiera o hotové, preverené teórie, a tak je skôr záležitost’ou

\footnotetext{
${ }^{7}$ Pozri napr. Govier $(2014,11)$, van Eemeren et al. $(2014,15)$.

${ }^{8}$ McKeon (2013) spochybňuje spomínaný konsenzus na úrovni produktov (vysvetlenia sú podla neho druhmi argumentov), no uznáva rozdiel na úrovni činnosti (rečové akty, ktoré vykonávame pri vysvetl'ovaní, sa ilokučnými zámermi líšia od rečových aktov, ktoré vykonávame, ked' argumentujeme). Jeho dôvodmi sa tu nemôžem podrobnejšie zaoberat'. $Z$ hl'adiska mojich zámerov stačí poznamenat', že McKeonovo rozlíšenie medzi explanačnými a evidenčnými argumentmi zodpovedá môjmu rozlíšeniu medzi vysvetleniami a argumentmi. Ak prijmeme McKeonov slovník, moja téza znie, že epistemicky najcennejšie explanačné argumenty bývajú podporené evidenčnými argumentmi.
} 
kontextu zdôvodnenia. Pritom platí, že primárne porozumenie je základom sekundárneho porozumenia: to druhé nie je možné bez toho prvého (Humphreys 2000, 270).

Humphreysovo rozlíšenie medzi dvomi druhmi porozumenia môžeme aplikovat' aj na explanácie. Vysvetlenia, ktorých výsledkom je sekundárne porozumenie, sa odvolávajú na vopred existujúce modely, teórie či zákony. Aby sme DN-vysvetlili, prečo sa kol'ajnice roztiahli, stačí, ak v báze poznania empirickej vedy identifikujeme vhodný zákon, overíme splnenie jeho antecedentu a explanandum podeň subsumujeme. Epistemický deficit, ktorý takto odstraňujeme, je len lokálny: týka sa jednotlivca alebo ohraničenej skupiny l'udí. Vysvetlenia tohto druhu budem d'alej nazývat' sekundárnymi vysvetleniami.

Naproti tomu vysvetlenia, ktoré prinášajú primárne porozumenie, formulujú výskumníci najprv sami pre seba. Používajú pritom prostriedky, ktoré sú aspoň sčasti výsledkom ich vlastného epistemického úsilia a pôvodne neboli $\mathrm{k}$ dispozícii. Takéto vysvetlenia majú za ciel' odstránit' globálny epistemický deficit. Umožňujú porozumiet' javom, resp. druhom javov, ktorých (uspokojivé) vysvetlenie dosial' nebolo vo vedeckej komunite známe. Ide o primárne vysvetlenia.

Primárne a sekundárne vysvetlenia sa líšia čo do epistemického statusu svojich zložiek. Propozície v explanansoch sekundárnych vysvetlení - a osobitne tie, ktoré opisujú pravidelnosti, mechanizmy či kauzálne histórie, a preto robia väčšinu explanačnej práce - sú najneskôr v čase formulácie vysvetlenia akceptované ako súčast' bázy poznatkov empirickej vedy. Inak povedané, z hl'adiska najlepšieho poznania, ktoré máme $\mathrm{k}$ dispozícii, o nich niet sporu. Podobne neproblematická je pri sekundárnych vysvetleniach otázka inferenčného vzt’ahu medzi explanansom a explanandom, teda napríklad otázka, či explanandum možno deduktívne odvodit' z explanansu, alebo či explanans poskytuje dostatočnú mieru (nededuktívnej) podpory explanandu.

Pri primárnych vysvetleniach musí byt' situácia z povahy veci iná, pretože inak by vo vzt’ahu k explanandu nemohol existovat' globálny epistemický deficit. Medzi klúčovými prvkami explanansu primárneho vysvetlenia teda môžu figurovat' propozície, ktoré nie sú súčast’ou bázy poznania a nemajú epistemický status akceptovaných poznatkov. Poznatok o tom, že medzi explanansom a explanandom existuje inferenčný vzt’ah, ktorý umožňuje vysvetlenie, takisto nemusí byt' súčast'ou bázy poznania. ${ }^{9}$

$\mathrm{Z}$ epistemického hl'adiska možno teda rozdiely medzi dvoma druhmi vysvetlení zhrnút' takto. Sekundárne vysvetlenia sa vyznačujú väčšou mierou spol'ahlivosti a dôveryhodnosti. Filozofia vedy si ich vyberá ako príklady práve preto, lebo z vecného

\footnotetext{
${ }^{9}$ Ide o túto situáciu: propozície, ktoré vystupujú v explananse, síce tvoria etablovanú súčast' poznatkov vedy, no explanandum (resp. jav, ktorý opisuje) dosial' zostávalo nevysvetlené, pretože o propozíciách v explananse nebolo známe, že postačujú na formuláciu vysvetlenia. Napríklad nebolo známe, že explanandum z nich možno deduktívne odvodit'.
} 
hl'adiska sa dajú považovat' za nepochybné, ${ }^{10}$ a tak možno upriamit' pozornost' na ich logickú štruktúru či iné metodologicky významné vlastnosti. Skúmanie vysvetlení vo filozofii vedy sa preto nemusí zaoberat' ani situáciami, v ktorých pýtajúci sa zareaguje na vysvetlenie d’alšou otázkou: „A prečo by som tomu mal verit?“. Praktický význam takých vysvetlení je však najmä didaktický. Kognitívne cenné sú len tam, kde ešte môžu odstránit’ lokálny epistemický deficit. Primárne vysvetlenia sú, naopak, kl'účovým faktorom celkového vedeckého pokroku. Cenou za ich väčší (potenciálny) epistemický prínos je, že musia čelit’ prirodzenému vedeckému skepticizmu a kritickým námietkam. Preto musia byt' podporené argumentmi.

\section{Argumenty v prospech vysvetlenia}

Primárne porozumenie je podla Humphreysa „zamerané dovnútra“, takže spočiatku je určené „výskumníkovi alebo výskumníkom, a nie iným“ (Humphreys 2000, 270). Ide o produkt, ktorý v závislosti od predmetu skúmania vzniká v laboratóriu, v teréne, $\mathrm{v}$ archíve, prípadne $\mathrm{v}$ teoretikovom kresle. Nosičom sekundárneho porozumenia sú zase učebnice. Ak chceme skúmat' primárne vysvetl'ovanie a jeho súvislost' $\mathrm{s}$ argumentáciou, potrebujeme text, ktorého súčast’ou je primárne vysvetlenie. Prirodzeným zdrojom takých textov sú významné vedecké časopisy. Predstavujú fóra, v ktorých sa primárne vysvetlenia stávajú verejnými, čím sa začína ich cesta do učebníc. Samozrejme, nie všetky články vo vedeckých časopisoch obsahujú primárne vysvetlenia, tak ako nie každý výskum je prípadom explanačného výskumu. Existuje však trieda textov, ktorých explanačné zámery sú zretel'né už z ich názvu.

Aj zbežný pohl'ad na štúdie tohto druhu ukazuje, že nepozostávajú len zo samého vysvetlenia. Primárne vysvetlenia sa odvolávajú na poznanie, ktoré sa v báze poznatkov vedy nenachádza, alebo je v nej prinajlepšom implicitné. Tento špecifický epistemický status explanansu sa premieta do podmienok úspešnosti rečového aktu primárneho vysvetlenia. Vo všeobecnosti platí, že primárne vysvetlenie nebude recipientom akceptované, ak produktor neobjasní, prečo by recipient mal prijat' epistemicky problematické zložky vysvetlenia. ${ }^{11}$ Súčast’ou textov, ktoré predkladajú primárne vysvetlenia, sú preto aj argumenty, ktorý ciel'om je poskytnút' vysvetleniam podporu.

10 Treba zdôraznit', že spol'ahlivost' sekundárnych vysvetlení nie je absolútna. Z dejín vedy poznáme množstvo prípadov, ked’ sa na nich založené porozumenie ukázalo ako iluzórne. Chybné explanansy sme spresnili alebo nahradili inými, prípadne sme dospeli k záveru, že sama otázka je nesprávne položená. Od podobných komplikácí́ tu v záujme jednoduchosti prevažne odhliadam, no budem sa venovat' aj prípadu, ked’ sa existujúce vysvetlenie považuje za neadekvátne, pričom sa namiesto neho ponúka iné.

11 Vo vedeckej komunikácii sa povinnost' splnit' túto podmienku predpokladá akoby automaticky a na jej praktické dodržanie dohliada napríklad recenzné konanie. Uvedené neznamená, že sekundárne vysvetlenia sa nemôžu stretnút's pochybnost'ami a vyžadovat' si vynaloženie epistemického úsilia či dodatočnú podporu pomocou argumentov - napríklad vo vzt’ahu k tvrdeniu, že antecedentné 
Čo však znamená podporit’ vysvetlenie argumentmi? Na prvé priblíženie nám poslúži prípad argumentu $\mathrm{v}$ prospech propozície, ktorá v d'alšom kroku figuruje vo vysvetlení ako súčast' explanansu. Schematicky možno tento postup zachytit' takto:

\begin{tabular}{lllll} 
& & Jazyková štruktúra & Komplexný rečový akt & Ilokučný zámer \\
\hline $\mathbf{1}$ & evidencia $\vdash_{i} e_{1}$ & úsudok & argumentácia & $\begin{array}{l}\text { zdôvodnit' } \\
\text { prijatel'nost' } e_{1}\end{array}$ \\
\hline $\mathbf{2}$ & $e_{1} \wedge \ldots \wedge e_{n} \vdash_{j} e_{x}$ & úsudok & vysvetl'ovanie & $\begin{array}{l}\text { priniest' } \\
\text { porozumenie o } e_{x}\end{array}$ \\
\hline
\end{tabular}

Symbol $\vdash_{i}$ tu zastupuje deduktívnu alebo nededuktívnu inferenčnú reláciu, $\vdash_{j}$ je explanačná relácia. Propozície $e_{1}, \ldots, e_{\mathrm{n}}$ sú tvrdenia, ktoré tvoria explanans; $e_{x}$ je explanandum. „Evidencia“ je konjunkcia výrokov, ktoré sa uvádzajú ako dôvody $\mathrm{v}$ prospech prijatia propozície $e_{1}$; môže, ale nemusí íst' o empirickú evidenciu v zmysle dát, ktoré potvrdzujú určitý výrok. Schéma zachytáva situáciu, ked' produktor presviedča recipienta o pravdivosti explanansu (resp. jeho časti), ktorý následne slúži na vysvetlenie explananda. Ked’že k podmienkam úspešnosti rečového aktu primárneho vysvetlenia patrí aj to, aby bola zdôvodnená jeho adekvátnost', akceptácia vysvetlenia závisí od úspešnosti tohto argumentu.

Táto štruktúra pripomína kombináciu subordinatívnej a koordinatívnej argumentácie, ktorú možno prostriedkami pragmadialektickej teórie argumentácie opísat' takto: ${ }^{12}$

(A) $1 e_{x}$

$1.1 e_{1}$

1.1.1 evidencia

$\cdots$

$1 . n e_{n}$

Tvrdenie 1.1.1 (evidencia) slúži na podporu tvrdenia 1.1 (prvok $e_{1}$ explanansu) a tvrdenia $1.1, \ldots, 1 . n$ spoločne podporujú tvrdenie 1 (explanandum $e_{x}$ ). Pri takejto rekonštrukcii je zretel’ná súvislost' medzi argumentáciou a vysvetlením, no zároveň sa

podmienky zákona v explananse sú splnené. Tvrdím však, že pri primárnych vysvetleniach sa s pochybnost'ami vždy vopred počíta, čomu sa prispôsobuje obsah a štruktúra komunikácie.

12 Pre nedostatok priestoru sa tu nemôžem venovat' podrobnejšiemu výkladu tejto notácie. Užitočný úvod do praktického použitia pragmadialektickej teórie argumentácie na rekonštrukciu argumentov ponúka (van Eemeren, Grootendorst, Snoeck Henkemans 2002, 63 - 87). 
stiera rozdiel medzi ilokučnými zámermi týchto rečových aktov. Hoci medzi tvrdeniami $1.1, \ldots, 1 . n$ a tvrdením 1 existuje určitá inferenčná relácia (napr. relácia DNvysvetlenia), neznamená to, že tvrdenie 1 , teda explanandum, môžeme považovat' za záver koordinatívnej argumentácie, ktorého prijatel'nost' majú podporit' tvrdenia $1.1, \ldots, 1 . n$. Explanandum tu nehrá úlohu záveru, o ktorého prijatel'nosti treba presviedčat'. Práve to však zápis (A) naznačuje.

Navyše ciel'om argumentácie v prospech primárneho vysvetlenia nemusí byt' len zdôvodnit' niektorý z prvkov explanansu. Akceptácia propozícií v explananse ako pravdivých je síce nutnou, no nie dostatočnou podmienkou adekvátnosti, a teda prijatel'nosti vysvetlenia. $\mathrm{Na}$ explanans, respektíve na reláciu vysvetlenia medzi explanansom a explanandom, sa zvyčajne kladú aj d’alšie podmienky. Nazvime ich „kritériá adekvátnej explanácie“ (KAE). Ide o podmienky, ktoré sú zväčša implicitné a ktorých splnenie sa štandardne očakáva od vysvetlení v empirickej vede, respektíve v konkrétnej disciplíne, oblasti výskumu či výskumnom programe. O ich explicitnú rekonštrukciu na všeobecnej úrovni sa pokúšajú modely vedeckého vysvetlenia vo filozofii vedy. V DN-modeli ide okrem pravdivosti aj o to, aby explanandum logicky vyplývalo z explanansu, aby explanans obsahoval najmenej jeden všeobecný zákon, alebo o to, aby všetky výroky v explananse boli empirickými výrokmi. V rôznych modeloch kauzálneho vysvetlenia sa zase očakáva, že explanans reprezentuje faktory, ktoré sú kauzálne relevantné pre výskyt vysvetl'ovaného javu. Výskumné programy v sociálnych vedách zase bežne pracujú s filozofickými predpokladmi o tom, čo konštituuje adekvátne vysvetlenie l'udského konania: niektoré uprednostňujú vysvetlenie na základe individuálnych preferencií a rozhodnutí, iné vyžadujú, aby sa konanie vysvetl'ovalo napríklad pomocou faktov o ekonomickej štruktúre spoločnosti.

Ked' predkladáme primárne vysvetlenie, splnenie týchto podmienok môže byt' sporné, a teda vyžadovat' si osobitné zdôvodnenie. Argumentácia v prospech vysvetlenia sa preto vo svojej úplnej podobe dá charakterizovat' ako argumentácia v prospech tézy

(TAE) „,e $e_{1} \wedge \ldots \wedge e_{n} \vdash_{j} e_{x}$ “ je adekvátnym vysvetlením $\leftrightarrow e_{1}, \ldots, e_{n}, e_{x}$ splńajú KAE.

Kritériá adekvátnej explanácie môžeme reprezentovat’ ako konjunkciu podmienok $K_{1}, \ldots, K_{m}$, ktoré sa vzt'ahujú na rôzne prvky vysvetlenia. Argumentovat' v prospech TAE potom znamená uviest' dôvody v prospech tvrdení, že prvky primárneho vysvetlenia (resp. prinajmenšom tie sporné) spíňajú jednotlivé podmienky $K_{1}, \ldots$, $K_{m}$. Argumentácia v prospech vysvetlenia má podobu komplexnej argumentácie, ktorá kombinuje subordinatívnu a koordinatívnu argumentáciu: 
(AE) $1, e_{1} \wedge \ldots \wedge e_{n} \vdash_{j} e_{x}$ “ je adekvátnym vysvetlením $e_{x} \leftrightarrow K_{1}\left(e_{1}\right) \wedge \ldots \wedge K_{m}\left(e_{1}, \ldots\right.$, $\left.e_{n}, e_{x}\right)$.

$1.1 K_{1}\left(e_{1}\right)$

1.1.1 evidencia 1

$1.2 K_{2}\left(e_{1}\right)$

1.2.1 evidencia 2

...

$1 . m K_{m}\left(e_{1}, \ldots, e_{n}, e_{x}\right)$

1.m.1 evidencia ${ }_{m}$

Evidencia $_{1}$ a evidencia 2 tu zastupujú konjunkcie výrokov, ktoré sa uvádzajú na podporu tvrdenia, že súčast' explanansu $e_{1}$ spĺn̆a podmienky $K_{1}$ a $K_{2}$ z množiny kritérií adekvátnej explanácie - napríklad podmienky DN-modelu, podl'a ktorých v explananse musí figurovat' všeobecný zákon a zároveň empirický výrok. Evidencia $a_{m}$ zase zdôvodňuje tvrdenie, že propozície vo vysvetlení, teda súčasti explanansu a explanandum, sú v relácii vymedzenej podmienkou $K_{m}$ - teda napríklad že explanandum možno deduktívne odvodit' z explanansu.

Produktor, ktorý predkladá primárne vysvetlenie určitého javu, chce maximalizovat' šancu, že vysvetlenie bude prijaté. Preto chce preukázat' jeho adekvátnost' vzhl'adom na KAE, ktoré patria k podmienkam úspešnosti rečového aktu vysvetlenia. Produktor počíta s tým, že recipient tieto kritériá akceptuje ako postačujúce na prijatie vysvetlenia. Argumentácia pri primárnom vysvetl'ovaní má teda „preemptívny“ charakter: jej ciel'om je vopred neutralizovat' prípadné pochybnosti o vysvetlení a zablokovat' námietky voči nemu. V závislosti od toho, ktoré aspekty predkladaného vysvetlenia produktor pokladá za potenciálne sporné, bude argumentácia v prospech splnenia kritérií bohatšia (teda zameria sa na zdôvodnenie splnenia väčšieho počtu $\mathrm{KAE}$ ), alebo naopak úspornejšia (teda niektoré tvrdenia tvaru $K_{s}\left(e_{t}\right)$ zostanú zamlčané, spolu s evidenciou ${ }_{s} \mathrm{v}$ ich prospech). Podobne môže zostat' zamlčaný záver, takže argumentácia bude mat' napríklad podobu jednoduchého zdôvodnenia pravdivosti propozícií z explanansu pomocou iných tvrdení.

Pri predkladaní primárneho vysvetlenia teda produktor vykonáva dva rečové akty. Jednak predkladá argument, ktorého úplný tvar zachytáva schéma AE, jednak formuluje vysvetlenie: 


\begin{tabular}{lllll} 
& & Jazyková štruktúra & Komplexný rečový akt & Ilokučný zámer \\
\hline $\mathbf{1}$ & $\begin{array}{l}\text { argument tvaru } \\
(\mathrm{AE})\end{array}$ & úsudok & argumentácia & $\begin{array}{l}\text { zdôvodnit' } \\
\text { adekvátnost' } \\
\text { vysvetlenia (2) }\end{array}$ \\
\hline $\mathbf{2}$ & $e_{1} \wedge \ldots \wedge e_{n} \vdash_{j} e_{x}$ & úsudok & & $\begin{array}{l}\text { priniest' } \\
\text { porozumenie o } e_{x}\end{array}$ \\
\hline
\end{tabular}

Skôr než argumentáciu v prospech primárneho vysvetlenia ilustrujem na príklade vedeckého textu, chcem obrátit' pozornost' na pomerne častý prípad formulácie primárneho vysvetlenia. Okrem situácií, ked' v báze poznatkov chýba vysvetlenie pre explanandum $e_{x}$, sa vyskytujú aj situácie, ked' určité vysvetlenie je síce k dispozícii, no novší výskum ukáže, že nie je adekvátne. Napríklad sa zistí, že faktory, ktoré sa v existujúcom vysvetlení považovali za príčinu výskytu daného (druhu) javu, preň v skutočnosti nie sú kauzálne relevantné, pričom pravou príčinou sú iné faktory. Podmienkou úspešnosti „nového“ vysvetlenia je potom odmietnutie existujúceho vysvetlenia. Okrem argumentácie v prospech vlastného vysvetlenia preto produktor musí ponúknut' argumentáciu $v$ neprospech konkurenčného vysvetlenia. ${ }^{13}$ Ciel'om je ukázat', že existuje najmenej jedna relevantná podmienka $K_{l}$ spomedzi KAE, ktorú niektorý z prvkov existujúceho vysvetlenia nespíña. Schematicky:

(NE) $1, e_{1^{*}} \wedge \ldots \wedge e_{n^{*}} \vdash_{j^{*}} e_{x}$ “ nie je adekvátnym vysvetlením $e_{x} \leftrightarrow \neg K_{1}\left(e_{1^{*}}\right) \vee \ldots \vee$ $\neg K_{m}\left(e_{1 *}, \ldots, e_{n^{*},}, e_{x}\right)$.

$1.1 \neg K_{l}\left(e_{1^{*}}\right)$

\subsection{1 evidencia $l^{*}$}

Evidencia $l^{*}$ je negatívna evidencia, ktorá umožňuje usúdit', že propozícia $e_{l^{*}}$ nespĺ́̆a podmienku $K_{1}$ - napríklad, že $e_{l *}$ je nepravda.

\section{Ilustrácia: Príčiny druhej vojny v Iraku}

Svoj návrh krátko ilustrujem na nedávnom článku amerického politológa Ahsana I. Butta (2019), ktorý predložil nové vysvetlenie invázie Spojených štátov do Iraku v roku 2003. Nie je vylúčené, že vo svetle budúceho výskumu sa ukáže ako neadekvátne. Pre potreby ilustrácie ho však budem považovat' za prípad adekvátneho primárneho vysvetlenia, čo evidentne zodpovedá zámerom autora. Text článku okrem formulácie samotného vysvetlenia zahŕňa aj argumentáciu, ktorá korešponduje so schémami (AE) a (NE).

13 O koexistencii konkurenčných vysvetlení ako o druhu nezhody pozri Bielik (2019). 
Podl’a Butta sa väčšina existujúcich vysvetlení invázie odvoláva na jednu alebo viaceré z troch príčin: (i) obavy USA z irackých zbraní hromadného ničenia, (ii) zámer USA získat' kontrolu nad irackou ropou, (iii) záujem USA o demokratizáciu Iraku. Buttovo nové vysvetlenie, naopak, označuje za hlavnú príčinu (iv) záujem USA posilnit' svoju pozíciu hegemóna $\mathrm{v}$ očiach svetového spoločenstva. $Z$ hl'adiska vysvetlenia možno Buttovu štúdiu rozdelit' na niekol'ko častí: 1. argumentáciu v neprospech vysvetlení na základe (i) - (iii); 2. náčrt teoretického rámca, ktorý opisuje mechanizmus performatívnej vojny; 3 . argumentáciu v prospech vysvetlenia na základe (iv); a 4. formuláciu vysvetlenia na základe (iv).

Spomedzi existujúcich vysvetlení Butt venuje najväčšiu pozornost’ vysvetleniu na základe príčiny (i), ${ }^{14}$ ked’že ho považuje za najrozšírenejšie. Ide o vysvetlenie zasadené do „rámca vyjednávania“:

(i) „Konkrétne, možnost’, že Irak získa jadrové zbrane, by v budúcnosti znamenala prudký zlom v rovnováhe moci. To prinútilo Spojené štáty stavit' na vítazstvo nad súperom, ktorého je relatívne lahšie porazit' dnes ako zajtra. Výsledkom bola preventívna vojna $[\ldots]$ “. (Butt 2019, 253).

Vysvetlenie sa teda odvoláva na dlhodobé súperenie medzi USA a Irakom $\left(e_{1 *}\right)$, d’alej na očakávanie USA, že pozícia Iraku sa výrazne posilní $\left(e_{2^{*}}\right)$, a napokon na zámer USA predíst' situácii, že by mali čelit' silnejšiemu Iraku $\left(e_{3 *}\right)$. Aby sme tieto propozície mohli využit' na formuláciu úplného vysvetlenia, museli by sme doplnit' niektoré zamlčané premisy, napríklad všeobecné tvrdenie, ktoré spája zámer racionálneho aktéra s jeho konaním, a tak umožňuje inferenciu od explanansu k explanandu. Z hl'adiska mojich zámerov sú však dôležitejšie argumenty, ktorými sa Butt usiluje toto vysvetlenie podkopat'.

Prvý sa týka propozície $e_{2}$. Butt tvrdí, že proponenti vysvetlenia (i) ju zdôvodňujú pomocou problematických zdrojov (Butt 2019, 254). Vieme síce, že vláda USA sa pokúšala presvedčit' obyvatel'stvo o spomínanej hrozbe, no to ešte neznamená, že ju sama brala vážne. O skutočných postojoch $\mathrm{v}$ tomto prípade nemôžeme usudzovat' iba na základe oficiálnych vyhlásení. Rôznorodá ústna a písomná evidencia $2_{2}^{*} \mathrm{z}$ prostredia spravodajských služieb, Pentagonu a Bieleho domu totiž naznačuje, že pravdepodobnost' úspešného rozvoja irackého jadrového programu sa $\mathrm{v}$ období pred inváziou považovala za nízku, ba dokonca za klesajúcu. Hoci predstavitelia USA sa verbálne hlásili k $e_{2 *}$, podl'a Butta existujú dobre dôvody mysliet' si, že v skutočnosti neboli presvedčení o hrozbe vyjadrenej $e_{2^{*}}$, ba ani o jej slabšej verzii v zmysle neistoty „čo ak...“.

14 Ďalej hovorím jednoducho o „vysvetlení (i)“a a pod. 
Ďalší argument sa týka spojenia medzi explanansom a explanandom. USA mohli mat' podl'a Butta aj iné, mierové možnosti, ako zabránit' rozvoju irackého jadrového programu:

„Vzhl’adom na to, že vojna je nákladná a že racionálni aktéri by mali preferovat’ mier pred vojnou, ak sa obidvomi dajú dosiahnut' podobné výsledky [...], je zvláštne, že Bushova vláda bola v období tesne pred vojnou taká odmietavá voči inšpekciám IAEA a stratégiám kontroly [containment]“ (Butt 2019, 260).

Vysvetlenie typu (i) by preto malo ukázat', že alternatívne postupy boli zablokované alebo vyčerpané, a preto nezostávala iná možnost' ako preventívna vojna. Navyše evidencia 2*' $^{\prime}$ tom, že USA tieto možnosti zámerne ignorovali (Butt 2019, 262), opät' spochybňuje dôveryhodnost' $e_{2 *}$.

Butt teda spochybňuje adekvátnost' vysvetlenia (i) pomocou argumentov, ktoré útočia na predpoklad o pravdivosti jednej zo súčastí explanansu $\left(e_{2^{*}}\right)$ a na inferenčný vzt’ah medzi explanansom a explanandom. Kritériá adekvátnej explanácie, na ktoré sa odvoláva, nie sú z textu zrejmé. Zdá sa však, že medzi ne zarad’uje pravdivost' propozícií $\mathrm{v}$ explananse a vzt’ah deduktívneho vyplývania medzi explanansom a explanandom. Je zrejmé, že spomínané argumenty možno jednoducho rekonštruovat' tak, aby spíñali schému (NE).

Pokial' ide o Buttovo vlastné vysvetlenie, jeho základom je „téza o performatívnej vojne“ (TPV), ktorú možno zhrnút' takto:

(TPV) ,[...] všetky štáty sú zainteresované na svojom statuse. Hegemonické [...] štáty sú na status osobitne citlivé, pretože ich vodcovská pozícia závisí od akceptácie menšími mocnost’ami a inými pozorovatel'mi. [...] Ked' existuje nezhoda medzi tým, ako mocný štát vníma svoj vlastný status, a tým, ako ho chápu ostatní, najmä po určitom ponižení, daná krajina sa môže rozhodnút' rozpútat' vojnu, aby iným v systéme dokázala svoju hegemóniu. Niektoré reputačné a statusové výhody možno získat' iba násilím [...] obet' preto nemôže ponúknut' nič materiálne ani symbolické, aby agresora uchlácholila [...]“ (Butt 2019, 268; kurzíva J. H.).

Pasáž vyznačená kurzívou tvorí akési jadro TPV (d’alej: $e_{1}$ ), ktoré pripomína všeobecný zákon. Butt sa ho usiluje zdôvodnit' pomocou odkazov na existujúce poznatky o konfliktoch, a to nielen na medzinárodnej úrovni, ale aj medzi jednotlivcami vo väzenskom prostredí (evidencia $a_{1}$; Butt 2019, 264 - 268). Nie je preto celkom zrejmé, či TPV v uvedenej podobe možno považovat' za súčast' bázy poznatkov vedy, alebo nie. Na to, aby sme Buttovo vysvetlenie považovali za primárne, však stačí, ak 
sú epistemicky problematické niektoré (nie všetky) súčasti explanansu, prípadne relácia medzi explanansom a explanandom.

Aby sa druhá vojna v Iraku dala pokladat' za prípad tohto druhu vojny, treba najmä preukázat', že boli splnené antecedentné podmienky jadra TPV. Za kl'účovú ponižujúcu udalost', ktorá spôsobila diskrepanciu medzi sebavnímaním Spojených štátov a postojom ostatných krajín, považuje Butt teroristické útoky z 11. septembra $2001\left(e_{2}\right)$. Ich význam pre status USA ako mocnosti zdôvodňuje odkazom na dobovú publicistiku a prieskumy verejnej mienky (evidencia2; Butt 2019, 268 - 370).

Okrem toho Butt predkladá argumenty $\mathrm{v}$ prospech tvrdenia, že posilnenie medzinárodnej reputácie štátu bolo dôležitou motiváciou konania predstavitel’ov USA $\left(e_{3}\right)$. Odkazuje pritom na interné rozhovory a rôzne dokumenty, na ktorých sa podielali členovia Bushovej vlády a ktoré hovorili o „demonštratívnom účinku“ pripravovanej vojny či o „príležitostiach na preukázanie schopností“, ktoré poskytuje (evidencia;; Butt 2019, 272 - 277). Propozíciu $e_{3}$ možno považovat' za d'alšiu súčast' antecedentných podmienok jadra TPV. Má sa ňou preukázat', že teroristické útoky skutočne viedli k situácii, v ktorej predstavitelia USA nadobudli presvedčenie o potrebe posilnit' status krajiny ako hegemóna.

Podobne Butt venuje pozornost' aj podpore tvrdenia, že USA vytvorili situáciu, v ktorej oponent nemal na výber. Poukazuje na to, že vojna sa začala skôr, ako boli vyčerpané ostatné možnosti (Butt 2019, 278), a že alternatívne stratégie neboli predmetom serióznych úvah (Butt 2019, 280). Reaguje tiež na potenciálnu výhradu, podl'a ktorej úlohu performatívneho konfliktu mohla hrat' už vojna v Afganistane, ktorá sa začala hned' po 11. septembri. Podl'a autora však z hl'adiska TPV nebola relevantná, pretože sa pokladala za primeranú odpoved' na útoky. Na vyslanie správneho odkazu „bola nevyhnutná určitá eskalácia a nevyberavost““ (Butt 2019, 370). Režim Saddáma Husajna bol vhodným ciel'om preto, lebo bol vojensky lepšie vybavený a podarilo sa mu prežit' predchádzajúcu porážku počas Vojny v Perzskom zálive. Buttova preemptívna argumentácia sa tu opiera o evidenciu zo súkromných rozhovorov predstavitel'ov USA.

Buttovo vysvetlenie invázie do Iraku teda znie:

(iv) „Po skúsenosti so stratou statusu v dôsledku 11. 9. boli Spojené štáty nútené oprášit' svoju reputáciu tvrdosti a nastolit' všeobecnú výstrahu výzvam voči svojej hegemónii. Preto boli nútené bojovat' [...] Irak bol vhodný na také cvičenie, lebo predstavoval hnisavú ranu na americkej hrdosti. Hegemón, ktorý chce mat' vyrovnané účty a byt' nositel’om nového globálneho poriadku, nemohol tolerovat' takúto neuzavretú záležitost”“ (Butt 2019, 282). 
Toto vysvetlenie je podporené dvoma nezávislými rečovými aktmi argumentácie. Ciel'om toho prvého je podkopat' alternatívne vysvetlenie. Zodpovedá schéme (NE). Druhý má za ciel' podporit' tie prvky nového vysvetlenia, ktoré sú epistemicky problematické, prípadne zablokovat' potenciálne námietky. Možno ho rekonštruovat' vo forme schémy (AE).

\section{Záver}

Epistemicky najcennejšie vysvetlenia umožňujú porozumiet' javom, pre ktoré dosial' veda nemala (adekvátne) vysvetlenie. Novost' týchto primárnych vysvetlení sa týka jednotlivých súčastí explanansu alebo inferenčnej relácie medzi explanansom a explanandom a tkvie $\mathrm{v}$ tom, že príslušné prvky vysvetlenia dosial' neboli súčastou bázy poznatkov vedy. Ich epistemický status je v tomto zmysle problematický. Prijatie vysvetlenia recipientom preto závisí od toho, či sa produktorovi podarí odstránit' pochybnosti recipienta o jeho prvkoch. Na to slúži argumentácia v prospech vysvetlenia, ktorej ciel’om je preukázat', že navrhované vysvetlenie spíňa kritériá adekvátnej explanácie.

Argumentácia a vysvetl'ovanie pritom zostávajú činnost'ami odlišného druhu. Ich výsledky, teda úsudky, ktoré sú argumentmi, a úsudky, ktoré sú vysvetleniami, takisto vieme odlíšit', ak máme dostatok informácií o dialogickom kontexte. Ako som však ukázal, existujú kognitívne zaujímavé a z hl'adiska filozofie vedy dôležité prípady, ked' sú oba druhy činností úzko prepojené. Úspech jednej činnosti v týchto prípadoch dokonca patrí medzi podmienky úspechu tej druhej. Rekonštrukcia primárnych vysvetlení $\mathrm{v}$ ich úplnej podobe sa preto nezaobíde bez vhodného teoretického rámca na rekonštrukciu argumentov, ktorými sa tieto vysvetlenia podporujú. Teória argumentácie by $\mathrm{v}$ tomto zmysle mala patrit' medzi štandardné nástroje filozofickej teórie vedeckého vysvetlenia, pokial' sa zaoberá deskripciou skutočných vysvetlení.

\section{Literatúra}

BEX, F., WALTON, D. (2016): Combining Explanation and Argumentation in Dialogue. Argument \& Computation, 7 (1), 55 - 68. DOI: https://doi.org/10.3233/AAC-180039

BIELIK, L. (2019): Druhy nezhody a ich (semi)formálna rekonštrukcia. Filozofia, 74 (9), 690 - 704. DOI: https://doi.org/10.31577/filozofia.2019.74.9.1

BUČEK, J., ZOUHAR, M. (2015): Argumentácia a médiá. Bratislava: Univerzita Komenského v Bratislave.

BUTT, A. I. (2019): Why did the United States Invade Iraq in 2003 ? Security Studies, 28 (2), 250 285. DOI: https://doi.org/10.1080/09636412.2019.1551567

VAN EEMEREN, F. H. (2014): Handbook of Argumentation Theory. Dordrecht: Springer.

VAN EEMEREN, F. H., GROOTENDORST, R., SNOECK HENKEMANS, A. F. (2002): Argumentation: Analysis, Evaluation, Presentation. Mahwah (NJ): Lawrence Erlbaum Associates.

GOVIER, T. (2014): A Practical Study of Argument. Boston: Wadsworth. 
GOVIER, T. (2018): Problems in Argument Analysis and Evaluation (Updated Edition). Windsor: Windsor Studies in Argumentation. Dostupné na: https://windsor.scholarsportal.info /omp/ index.php/wsia/catalog/book/43 (Navštívené 19. 7. 2020).

HUMPHREYS, P. W. (2000): Analytic versus Synthetic Understanding. In: Fetzer, J. H. (ed.): Science, Explanation, and Rationality: Aspects of the Philosophy of Carl G. Hempel. Oxford: Oxford University Press, 267 - 286.

MCKEON, M. W. (2013): On the Rationale for Distinguishing Arguments from Explanations. Argumentation, 27 (3), 283 - 303. DOI: https://doi.org/10.1007/s10503-012-9288-1

DE REGT, H. W. (2017): Understanding Scientific Understanding. Oxford: Oxford University Press.

SNOECK HENKEMANS, A. F. (2001): Argumentation, Explanation and Causality: An Exploration of Current Linguistic Approaches to Textual Relations. In: Ted Sanders - Joost Schilperoord - Wilbert Spooren (eds.): Text Representation: Linguistic and Psycholinguistic Aspects. Amsterdam: John Benjamins Publishing Company, 231 - 246.

ZOUHAR, M. (2019): Subjektívny vkus a argumentácia. Filozofia, 74 (9), 754 - 767. DOI: https://doi.org/10.31577/filozofia.2019.74.9.5

Táto práca bola podporená Agentúrou na podporu výskumu a vývoja na základe Zmluvy č. APVV-17-0057.

Juraj Halas

Filozofická fakulta UK v Bratislave

Katedra logiky a metodológie vied

Gondova 2

81102 Bratislava 1

Slovenská republika

e-mail: juraj.halas@uniba.sk

ORCID: https://orcid.org/0000-0003-2455-9354 